series of 19 cases of Heard et al. (1963) the mean duration of symptoms was four to five months. This suggests that prolonged investigation and indecision are undesirable in the management of these cases.

\section{Summary}

Five cases of visceral ischaemia are presented. Successful operative and clinical results were obtained in three of the four cases of chronic intestinal ischaemia and in one case of coeliac axis stenosis.

Malabsorption was a feature of four cases. Abnormalities of faecal fat, jejunal histology, disaccharidase activity, and bromsulphalein excretion were present, and improvement or reversion to normal followed successful operation.

Chronic intestinal ischaemia should be strongly suspected in middle-aged patients with atypical abdominal pain and loss of weight, especially when alimentary carcinoma is suspected and barium studies are negative. Successful revascularization of the abdominal viscera can be achieved when the diagnosis has been proved by lateral aortography.
We wish to thank Mr. C. J. Longland for permission to include Case 2 in this report and Dr. D. Murray for the histological examination of the intestinal biopsies.

\section{REFERENCES}

Brolin, I., and Hansson, L. O. (1960). Acta chir. scand., 128, 261.

Dardik, H., Seidenberg, B., Parker, J. G., and Hurwitt, E. S. (1965). 7. Amer. med. Ass., 194, 1206.

Dunphy, J. E. (1936). Amer. F. med. Sci., 192, 109.

Fry, W. J., and Kraft, R. O. (1963). Surg. Gynec. Obstet., 117, 417.

Heard, G., Jefferies, J. D., and Peters, D. K. (1963). Lancet, 2, 975.

Marable, S. A., Molnar, W., and Beman, F. M. (1966). Amer. F. Surg., 111, 493.

Mavor, G. E., and Lyall, A. D. (1962). Lancet, 2, 1143.

Chrystal, K. M. R., and Tsapogas, M. (1963). Brit. F. Surg.,

50, 219.
Mikkelsen, W. P. (1957). Amer. 7. Surg., 94, 262.

Morris, G. C., jun., Crawford, E. S., Cooley, D. A., and DeBakey, M. E. (1962). Arch. Surg., 84, 95

DeBakey, M. E., and Bernhard, V. (1966). Surg. Clin. N. Amer., 46, 919.

Paton, E., Murray, E., and Watson, W. C. (1966). Brit. med. J., 1, 459.

Ranger, I., and Spence, M. P. (1962). Ibid., 2, 95.

Rob, C. (1965). Bibl. gastroent. (Basel), 8, 149.

Shaw, R. S., and Maynard, E. P. (1958). New Engl. F. Med., 258, 874

Watson, W. C., Paton, E., and Murray, D. (1965). Lancet, 2, 47.

\title{
Controlled Trials of a Sulphonamide Given Weekly to Prevent Exacerbations of Chronic Bronchitis
}

\author{
A. PINES,* M.D., M.R.C.P.ED.
}

Brit. med. F., 1967, 3, 202-204

Purulent exacerbations are difficult to prevent in patients with chronic bronchitis. Trials of antibiotics administered continuously for long periods have given variable and often negative results (Elmes, 1962). Most of these studies have been in outpatients, in whom regular treatment and exact assessment are notoriously difficult (Porter, 1966). I present the results of a controlled trial of a new sulphonamide given weekly to hospital inpatients with chronic bronchitis.

Sulphormethoxine (Fanasil) is a sulphonamide with a halflife in the body of 100 to 200 hours, so that it is effective if given once weekly. In a preliminary study in this hospital it was found to have some effect in mild exacerbations of chronic bronchitis, especially when given in a 2-g. dose weekly. A weekly dose over long periods is so convenient that it seemed worth assessing the value of the drug in preventing purulent exacerbations of chronic bronchitis.

\section{First Trial}

Many of the patients in this hospital stay for long periods because of medical or social reasons, or both. Patients who suffered from chronic bronchitis were eligible for the trial if (1) they were going to stay for long periods ; (2) had a history of at least one acute exacerbation during the previous 12 months as defined by hospital admission, treatment by antibiotics, or confinement to bed at home; and (3) had purulent sputum at the time of admission.

Plan of Trial.-In all patients the initial purulence of the sputum was cleared with courses of antibiotics. They were then divided into two groups by random selection, in a proportion of two treated to one control. Cards with treatment or control written on them were placed in sealed envelopes at

- Ware Park Hospital, Ware, Herts. random and taken in strict order of entry into the trial. As it was anticipated that many of the controls would relapse, this ratio would allow more patients to be treated. The treated patients were given sulphormethoxine $2 \mathrm{~g}$. once weekly. The control patients were given symptomatic treatment only. Because sulphormethoxine is a relatively new drug in this country, a double-blind trial with a placebo as well was not thought advisable, so that a close watch could be kept for any toxicity. No antibiotics were given to patients in either group unless a purulent exacerbation occurred. The patients were admitted to the trial from January 1964 until October 1964.

Patients.-All the patients were men. Most were aged from 40 to 70 (Table I). All had had symptoms of bronchitis for at least five years. Both groups were comparable in age (Table I) and in initial distribution of quantity of sputum (Table II). The method of allocation ensured that patients entered the trial in balanced proportions during each month of the year. Those

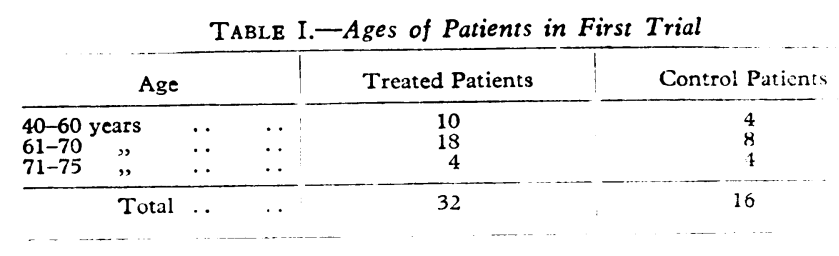

TABLE II.-Results According to Initial Quantity of Sputum in First

\begin{tabular}{|c|c|c|c|c|}
\hline \multirow{2}{*}{ Sputum Quantity } & \multicolumn{2}{|c|}{ Treated Patients } & \multicolumn{2}{|c|}{ Control Patients } \\
\hline & Success & Failed & Success & Failed \\
\hline $\begin{array}{l}\text { Less than } 30 \mathrm{ml} \text {. daily } \\
30 \mathrm{ml} \text { or more daily } .\end{array}$ & $\begin{array}{r}17 \\
4 \\
\end{array}$ & $\begin{array}{l}3 \\
8 \\
\end{array}$ & $\begin{array}{l}3 \\
1 \\
\end{array}$ & $\begin{array}{l}9 \\
3 \\
\end{array}$ \\
\hline Total .. & 21 & 11 & 4 & 12 \\
\hline
\end{tabular}


patients who did not relapse were observed for at least four months and some for up to eight months.

Daily Observation.-A 24-hour specimen of sputum was examined for purulence and quantity. Sputum purulence was graded into three categories-mucoid, with at the most a trace of pus ; grade 1 purulence when up to $50 \%$ of the specimen was purulent; and grade 2 purulence when over $50 \%$ was purulent. This was assessed daily by an independent observer, an experienced charge nurse who was completely unaware of whether patients were being treated or not. An exacerbation was diagnosed when the sputum became purulent, either grade 1 or grade 2 , for three successive days, whether accompanied by fever or other manifestations or not. Most patients did in fact feel ill and had fever. They were then withdrawn from the trial and the exacerbation treated with an antibiotic. Only the independent and "blind" assessment of the sputum was taken into consideration.

The sputum was tested routinely at monthly intervals or at the time of an exacerbation for pathogenic bacteria, though these were not tested for sensitivity to sulphormethoxine. The haemoglobin, white count, and urine were tested monthly and a blood urea was taken initially. The assessments of respiratory function and additional biochemical data were regarded as unimportant in this trial and were not carried out routinely.

Results.-There were no withdrawals except where an exacerbation occurred. Of the 16 control patients exacerbations took place in $12(75 \%)$. Of the 32 patients treated with sulphormethoxine exacerbations occurred in $11(35 \%)$. There were no exacerbations in $4(25 \%)$ of the 16 controls and in $21(66 \%)$ of the 32 treated patients. The difference in the percentage of exacerbations is $40 \%$, which is three times the standard error of $13.68 \%$. The $95 \%$ confidence interval for the true difference is $14-68 \%$. Sulphormethoxine seemed more successful in those patients who expectorated less than $30 \mathrm{ml}$. of sputum daily at the beginning of treatment (Table II).

\section{Second Trial}

Because of the success of sulphormethoxine and its lack of toxicity, a further trial was carried out during the winter of 1965-6. This was "double-blind" in a group of 60 patients similar to those in the first trial, again with independent assessment of the purulence of the daily 24-hour specimen of sputum. Four tablets of placebo or of sulphormethoxine ( 2 g.) were given weekly for a period of 10 weeks, whether relapse occurred or not.

Ten weeks' supply of tablets for each patient had been placed in a bottle by Roche Products Ltd. and numbered. The order in which either placebo or sulphormethoxine was issued was determined at random (Fisher and Yates) in a proportion of two treated to one placebo. The key to the trial was kept in a sealed envelope and not opened until both the trial and the final assessments of all patients had been completed. Though it would have been preferable for patients to continue throughout the winter in the trial, few would have stayed long enough in hospital to allow this assessment.

Patients.-Four had to be withdrawn from the trial, leaving 56 patients. Most were aged between 40 and 70 (Table III). All had had symptoms of bronchitis for at least five years (Table IV). In many patients an initial maximal peak flow reading had been obtained (Table $V$ ), and almost all showed a severe ventilatory defect. The placebo-treated patients tended to be younger, to have a shorter history of disease, to have less sputum (Table VI), and, in those tested, to have a higher range of maximal peak flow.

Results.-Three sulphormethoxine-treated patients were withdrawn (one discharged himself, cultures were positive for Mycobacterium tuberculosis in the second, and in the third an eosinophilia of $15 \%$ was present in the sputum). One control patient was withdrawn (eosinophilia in the sputum, 10\%). In the placebo group exacerbations occurred in $13(68 \%)$ out of 19 patients, and in the sulphormethoxine group in $14(38 \%)$ out of 37 . There were no relapses in $6(32 \%)$ placebo-treated patients and in $23(62 \%)$ sulphormethoxine-treated patients. The difference in the proportion of exacerbations is $30 \%$, which is more than twice the standard error of $13.35 \%$. The $95 \%$

\begin{tabular}{|c|c|c|c|}
\hline \multicolumn{2}{|c|}{ Age } & Treated Patients & Control Patients \\
\hline $\begin{array}{l}40-60 \text { years } \\
61-70 " \\
71-75 " \\
\end{array}$ & $\begin{array}{ll}\cdots & \cdots \\
\cdots & \cdots \\
\end{array}$ & $\begin{array}{r}6 \\
23 \\
8 \\
\end{array}$ & $\begin{array}{r}7 \\
10 \\
2\end{array}$ \\
\hline Tot: & . $\quad \ldots$ & 37 & 17 \\
\hline
\end{tabular}

TABLB IV.-Duration of Symptoms in Second Trial

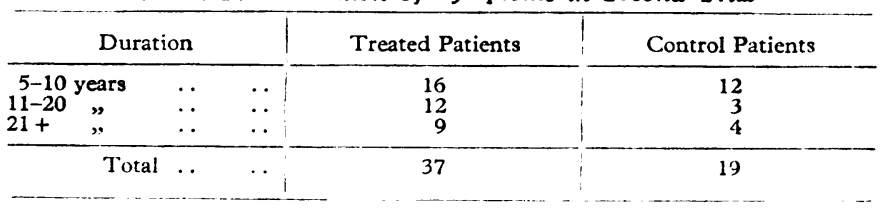

TABLE V.-Initial Maximal Peak Flow Rates in Second Trial

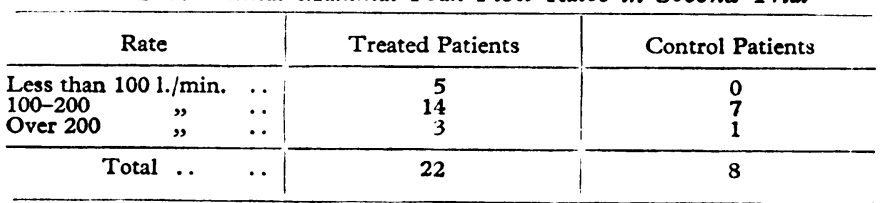

TABLB VI.-Results According to Initial Quantity of Sputum in Second

\begin{tabular}{|c|c|c|c|c|}
\hline \multirow{2}{*}{ Sputum Quantity } & \multicolumn{2}{|c|}{ Treated Patients } & \multicolumn{2}{|c|}{ Control Patients } \\
\hline & Success & Failed & Success & Failed \\
\hline $\begin{array}{l}\text { Less than } 30 \text { ml. daily .: } \\
30 \text { ml. or more daily } . .\end{array}$ & $\begin{array}{r}16 \\
7\end{array}$ & $\begin{array}{l}5 \\
9\end{array}$ & $\begin{array}{l}5 \\
1\end{array}$ & $\begin{array}{l}7 \\
6\end{array}$ \\
\hline Total .. & 23 & 14 & 6 & 13 \\
\hline
\end{tabular}

confidence interval for the true difference is $3-51 \%$. More exacerbations occurred among those patients who had over 30 ml. of sputum daily, both those treated and the controls. In those patients who had exacerbations there was a mean of 2.1 illnesses in 10 weeks among those sulphormethoxine-treated and of 1.5 among the controls. This may be related to the milder bronchitis which predominated among the latter.

\section{Comment}

When the results of both trials are combined the difference in the proportion of exacerbations is $35 \%$ and the standard error 9.603 . The $95 \%$ confidence interval for the true difference lies between 16 and $54 \%$.

Toxicity.-No toxicity or intolerance was found among any of the patients in either trial.

Bacteriology.-In both trials sputum was tested monthly as a routine. In the first trial Haemophilus influenzae was found at some time in 12 out of 48 patients and Streptococcus pneumoniae in five. In the second trial $H$. influenzae was found in eight and Str. pneumoniae in three. These results are too scanty to merit further analysis.

\section{Discussion}

The sulphonamides are generally held to be effective in vitro against Str. pneumoniae and $H$. influenzae: sulphormethoxine is equally effective in vitro (E. Bohni, personal communication, 
1966). With $2 \mathrm{~g}$. once weekly of sulphormethoxine plasma levels of free sulphonamide lie between 15 and $20 \mathrm{mg}$. $/ 100 \mathrm{ml}$. throughout the week, which may be comparable to that found with daily sulphadimidine by Newbould and Kilpatrick (1960). The mean half-life is 180 hours. Sulphormethoxine $1 \mathrm{~g}$. weekly gives slightly lower levels (Clarke, 1964).

In previous work on the prophylaxis of chronic bronchitis sulphonamides have not been shown to be effective (Kilpatrick and Oldham, 1954 ; Edwards et al., 1957 ; Francis et al., 1964). However, Clarke (1964), Aguirre and Casado (1964), and Frank (1964) were impressed with sulphormethoxine in preliminary studies. With sulphormethoxine the results I have described show a definite prophylactic effect in hospital inpatients. The number of exacerbations was significantly reduced. The initiation of many relapses must often be outside the control of ordinary chemotherapy (Scadding, 1966). Nevertheless, these results are better than in most other studies utilizing antibiotics, which have usually shown no reduction in the number of acute exacerbations (Scadding, 1966). These studies with antibiotics have shown reduction in the length of the acute illness (Scadding, 1966), but this was not so with sulphormethoxine. Naturally, inpatient conditions are more sheltered; an outpatient investigation on the effect of sulphormethoxine would be necessary on a larger scale and for longer than is possible in hospital before advocating its widespread use.

Perhaps sulphormethoxine is more effective than other longacting sulphonamides: the percentage of protein-binding is less than with sulphadimethoxine (Madribon), especially in higher levels, so that more diffusible and active sulphonamide is available. The effect of protein-binding on activity is sometimes uncertain and paradoxical (Brit. med. F., 1966). The steady effect throughout the week is likely to suppress the growth of $H$. influenzae and Str. pneumoniae once the major proportion of the infecting population has been eradicated by the more powerful antibiotics. Sulphonamides are said to be inactivated in the presence of pus, so that it is important to clear this from the bronchi so far as is possible before starting chemoprophylaxis. This may explain why sulphormethoxine was not very effective in treating an actual exacerbation in the preliminary study, or in reducing the duration of each acute illness during the trials. It may be a reason why others have obtained poor results with sulphonamides alone when treating patients in whom varying amounts of pus may often have been present in the sputum at the beginning of treatment.

The tolerability of sulphormethoxine and its ease of administration once weekly are important advantages over the antibiotics used in the prophylaxis of purulent exacerbations of bronchitis. During the course of much experience with sulphormethoxine side-effects have occurred in about $2 \%$ of patients. These consisted mainly of headache, nausea, and vomiting, but very occasional cases have been described of allergic skin rashes and leucopenia, all ending in recovery. The incidence of these effects is certainly no higher than with other sulphonamides, and appears insignificant compared with the seriousness of repeated purulent exacerbations of chronic bronchitis. Theoretically the time that sulphormethoxine remains in the body may prolong sensitivity reactions. Never- theless, experience has shown that reactions last for no longer than with short-acting sulphonamides.

\section{Summary}

Sulphormethoxine (Fanasil) is a sulphonamide which if administered once weekly gives effective levels over the whole week. Two such trials are described in hospital long-stay inpatients suffering from chronic bronchitis and in whom the initial purulence of the sputum had been cleared with antibiotics. Assessment was by "blind" independent evaluation of the daily 24-hour sputum for purulence.

In the first trial $11(34 \%)$ out of 32 treated patients relapsed, as did $12(75 \%)$ out of 16 given symptomatic treatment only (95\% confidence interval $14-68 \%$ ). In the second trial there were relapses in $14(38 \%)$ out of 37 treated patients and in 13 $(68 \%)$ out of 19 given a placebo only ( $95 \%$ confidence interval $3-57 \%$ ). If the results of both trials are combined the $95 \%$ confidence interval is $16-54 \%$.

There were no side-effects.

Sulphormethoxine shows significant prophylactic benefit in patients with chronic bronchitis and should be assessed on a larger scale in outpatients.

I wish to thank the medical, nursing, and secretarial staff of Ware Park Hospital for their help; the physicians who sent me their patients ; Dr. D. Linsell and Dr. P. D. Griffiths and their staff, of the Pathological Laboratory, Hertford County Hospital, for the pathological investigations; Mr. M. Hills, London School of Hygiene and Tropical Medicine, for his statistical advice; Dr. I. Lenox-Smith, Roche Products Ltd., for supplies of sulphormethoxine, for criticism, and for the unpublished information about this drug which I have quoted; and Professor J. W. Crofton, University of Edinburgh, for criticism.

A short version of this paper was given at the Fourth International Congress for Infectious Diseases, Munich, April, 1966.

ADDENDUM.-Recent but as yet unpublished experience on a very large scale during an outbreak of meningococcal meningitis, in which sulphormethoxine was used prophylactically in very high and repeated doses, has shown that the drug can occasionally produce skin reactions. These usually occurred in children, were mild, and followed a benign course. In some cases, however, they were generalized, more severe, and showed features of Lyell's syndrome.

\section{REFERENCES}

Aguirre, M., and Casado, J. (1964). 3rd International Congress of Chemotherapy, Stuttgart, 1963, edited by H. P. Kuemmerie, and P. Preziosi, vol. 1, p. 672 .

Brit. med. F., 1966, 1, 1059.

Clarke, G. B. M. (1964). 3rd International Congress of Chemotherapy, Stuttgart, 1963, edited by $\mathrm{H}$. Kuemmerie and P. Preziosi, vol. 1, p. 680 .

Edwards, G., Buckley, A. R., Fear, E. C., Williamson, G. M., and Zinnemann, K. (1957). Brit. med. F., 2, 259.

Elmes, P. (1962). Irish f. med. Sci., 6th Series, p. 243.
Francis, R. S., May, J. R., and Spicer, C. C. (1964). Brit. med. F., 1, 728 .

Frank, A. (1964). Wien. klin. Wschr., 76, 668.

Kilparrick, G. S., and Oldham, P. D. (1954). Brit. med. f., 2, 385.

Newbould, B. B., and Kilparrick, R. (1960), Lancet, 1, 887.

Porter, A. M. W. (1966). Brit. med. F., 1, 1301.

Scadding, J. G. (1966). Ibid., 1, 1281 . 